\begin{tabular}{|c|c|c|c|}
\hline \multirow{2}{*}{$\begin{array}{r}\text { Case Reports in } \\
\text { Gastroenterology }\end{array}$} & \multicolumn{2}{|c|}{ Case Rep Gastroenterol 2016;10:283-291 } & \multirow[b]{2}{*}{$\begin{array}{l}\text { Karger } \\
\text { Open access }\end{array}$} \\
\hline & $\begin{array}{l}\text { DOI: 10.1159/000445105 } \\
\text { Published online: June 14, } 2016\end{array}$ & $\begin{array}{l}\text { (C) } 2016 \text { The Author(s) } \\
\text { Published by S. Karger AG, Basel } \\
\text { www.karger.com/crg }\end{array}$ & \\
\hline & $\begin{array}{l}\text { This article is licensed under } \\
\text { International License (CC BY-N } \\
\text { Usage and distribution for comm }\end{array}$ & $\begin{array}{l}\text { nons Attribution-NonCommercia } \\
\text { ger.com/Services/OpenAccessLice } \\
\text { uires written permission. }\end{array}$ & \\
\hline
\end{tabular}

\title{
Long-Term Clinical Remission in Biologically Naïve Crohn's Disease Patients with Adalimumab Therapy, Including Analyses of Switch from Adalimumab to Infliximab
}

\author{
Tsutomu Mizoshita Satoshi Tanida Keiji Ozeki Takahito Katano \\ Takaya Shimura Yoshinori Mori Eiji Kubota Hiromi Kataoka \\ Takeshi Kamiya Takashi Joh \\ Department of Gastroenterology and Metabolism, Nagoya City University Graduate \\ School of Medical Sciences, Nagoya, Japan
}

\section{Keywords}

Biologically naïve Crohn's disease - Adalimumab - Infliximab · Serum trough level

\begin{abstract}
There is little evidence regarding the maintenance of long-term clinical remission by adalimumab (ADA) therapy in Crohn's disease (CD) patients naïve to anti-tumor necrosis factor treatment (naïve $C D$ patients), since most $C D$ patients are treated with $A D A$ after infliximab (IFX) therapy. The long-term clinical response to ADA was retrospectively analyzed in 17 naive $C D$ patients for at least 24 months, and the serum trough IFX levels were evaluated in patients switching from ADA to IFX. Of the 17 naive CD patients, 14 (82.4\%) maintained longterm clinical remission with ADA therapy for at least 24 months, without serious adverse events. The clinical condition of 7 patients was observed for more than 36 months, and 3, 1, 1 , and 2 cases maintained remission at months $42,48,54$, and 60 after ADA therapy, respectively. Three patients (17.6\%) switched from ADA to IFX less than 24 months after the start of ADA therapy, and they had remission, retaining trough levels of IFX higher than $1 \mu \mathrm{g} / \mathrm{ml}$, occasionally by dose escalation. In conclusion, maintenance ADA therapy achieves long-term
\end{abstract}


clinical remission in naïve CD patients. Switching from ADA to IFX is an important therapeutic option in $C D$ patients showing loss of response to $A D A$, occasionally with dose escalation, based on the analysis of serum IFX trough levels.

\section{Introduction}

Inhibition of tumor necrosis factor (TNF)- $\alpha$ is very important for control of inflammatory lesions in Crohn's disease (CD), and two TNF- $\alpha$ inhibitors, subcutaneous adalimumab (ADA, a fully human monoclonal antibody) and intravenous infliximab (IFX, a chimeric monoclonal antibody), are approved for treatment of CD in Japan [1]. In Japan, ADA is effective in inducing and maintaining clinical remission in patients with moderate-to-severe CD and is well tolerated, particularly in patients naïve to anti-TNF treatment [2], as shown in the CLASSIC I and CLASSIC II trials [3, 4]. Regarding maintenance of clinical remission with ADA therapy for more than 1 year, data after 2 and 4 years of ADA therapy for CD have been reported in the results of the CHARM and ADHERE clinical trials [5]. ADA was successful in the majority of patients, with a $10 \%$ loss of response (LOR) per subsequent year during 2 years of therapy for CD [6]. However, especially in Japan, there is little evidence regarding the maintenance of clinical remission associated with ADA therapy for more than 1 year in $C D$ patients undergoing treatment with ADA as the first TNF- $\alpha$ inhibitor (patients naïve to antiTNF treatment), since most CD patients are treated with ADA after IFX therapy.

Regarding the selection of TNF- $\alpha$ inhibitors in CD patients, IFX, not ADA, is used in most cases as the first TNF- $\alpha$ inhibitor, given that IFX received US Food and Drug Administration (FDA) approval in 1998, while ADA received FDA approval only in 2007. In Japan, IFX was approved more than 10 years earlier, while ADA was approved in 2010 for use in CD. Therefore, most patients have switched from IFX to ADA, while there is only one report of switching from ADA to IFX after primary/secondary failure or intolerance to a first TNF- $\alpha$ inhibitor [7]. Switching from ADA to IFX may be useful in CD patients who develop adverse effects or LOR, but a benefit from IFX to primary nonresponders has not been established [8]. As a result, there is little evidence for switching from ADA to IFX in CD patients. Regarding IFX therapy in CD patients, it is well known that the serum trough concentration of IFX predicts clinical outcome, and that LOR is related to a decrease in serum trough level [9]. CD patients with IFX trough levels higher than $1 \mu \mathrm{g} / \mathrm{ml}$ had a higher chance of achieving steroid-free clinical remission than those with lower IFX trough levels [10].

In the present study, the long-term clinical response to ADA in patients with CD treated with ADA as the first TNF- $\alpha$ inhibitor (patients naïve to anti-TNF treatment) for at least 24 months was analyzed retrospectively. In addition, the clinical response to IFX in patients with CD who switched from ADA to IFX was evaluated, analyzing serum trough IFX levels.

\section{Subjects and Methods}

\section{Patients}

Between December 2010 and December 2015, 17 consecutive active CD patients [CD activity index (CDAI) score $\geq 150$ ] naïve to anti-TNF treatment were administered subcutaneous ADA at the Nagoya City University Hospital after informed consent was obtained. Before the start of ADA treatment, infectious enteritis, such as that caused by bacteria and cytomeg- 
alovirus, was ruled out by stool cultures, Clostridium difficile toxin testing, and pathological analysis of the lesions [1].

\section{Treatment with ADA and IFX and Measurement of Serum IFX Levels}

According to the Japanese protocol, the patients received 160 mg of ADA by subcutaneous administration at week 0 , and $80 \mathrm{mg}$ at week 2; subsequently, subcutaneous doses of 40 mg were given as maintenance therapy every other week thereafter [1]. IFX was administered at $5 \mathrm{mg} / \mathrm{kg}$ to patients with active CD at weeks 0,2 , and 6 , and intravenous IFX injections of $5 \mathrm{mg} / \mathrm{kg}$ were given as maintenance therapy every 8 weeks thereafter, in accordance with the Japanese protocol [9]. If the CD patients showed LOR to $5 \mathrm{mg} / \mathrm{kg}$ of IFX, the dose was escalated to $10 \mathrm{mg} / \mathrm{kg}$ [11].

Serum IFX levels were measured using an enzyme-linked immunosorbent assay at Mitsubishi Tanabe Pharma Corporation (Osaka, Japan) [11] with written informed consent, and the protocol was approved by the Institutional Review Board at Nagoya City University Hospital.

\section{Symptoms and Laboratory Assessment}

Disease activity before and after TNF- $\alpha$ inhibitor administration (subcutaneous ADA and intravenous IFX) was measured using the CDAI score [3]. Response was defined as a reduction of $\geq 70$ points (70-point response) or $\geq 100$ points (100-point response) from month 0 in CDAI score, and remission was defined as a CDAI score $<150$ points [3]. The CDAI was evaluated every 6 months from month 0 to December 2015.

The definition of flare-up or LOR was made as previously described [11]. The disease condition was evaluated using not only CDAI scores but also C-reactive protein (CRP; normal value $\leq 0.30 \mathrm{mg} / \mathrm{dl}$ ), endoscopic findings, and computed tomography (CT) [1].

\section{Results}

\section{Patients' Characteristics}

The baseline characteristics of the 17 patients receiving subcutaneous ADA therapy are shown in table 1. All patients received treatment with ADA as the first TNF- $\alpha$ inhibitor. The male/female ratio was $11 / 6$, and the median ages at diagnosis and start of therapy were 31.9 years (range 19-52) and 36.4 years (19-64), respectively. The median disease duration was 5.6 years (0.1-21). The 17 cases were divided into $4 \mathrm{~L} 1,5 \mathrm{~L} 2$, and $8 \mathrm{~L} 3$ types according to the Montreal classification of CD. Six cases had perianal disease, and 3 cases had previously had surgical resection. Regarding surgical resection, 2 cases had had ileocecal resection, and 1 had had ileocecal resection and resection of a stricture in the small intestine twice. Regarding concomitant medications, 5 patients received prednisolone, 14 received 5-aminosalicylates, 6 received immunosuppressants [azathioprine (AZA)], 5 received granulocyte and monocyte adsorptive apheresis therapy, and 4 received enteral nutrition; none of them had previously used IFX or biologics (table 1). Also, none of the patients had serious adverse events requiring termination of ADA therapy. One case had hypertension, which was controlled by medication. 


\section{CDAI Scores in CD Patients Treated with ADA as the First TNF- $\alpha$ Inhibitor for at Least 24 Months}

Of the $17 \mathrm{CD}$ patients naïve to anti-TNF treatment, 14 (82.4\%) had subcutaneous ADA therapy for at least 24 months (table 2). All 14 patients (ADA-long-1-14) maintained remission at month 24 after the start of ADA therapy. The clinical conditions of 10 patients (ADAlong-1-10) were observed for at least 36 months, and all 10 patients maintained remission at month 36 after the start of ADA therapy. The clinical conditions of 7 cases (ADA-long-1-7) were observed for more than 36 months, and 3, 1, 1, and 2 cases maintained remission at month 42, 48, 54, and 60, respectively, after the start of ADA therapy (table 2). All 14 cases maintained remission with ADA as the first TNF- $\alpha$ inhibitor.

CD Patients Who Switched from ADA to IFX and Measurement of Serum IFX Levels Of the $17 \mathrm{CD}$ patients treated with ADA as the first TNF- $\alpha$ inhibitor, $3(17.6 \%)$ switched from ADA to IFX less than 24 months after the start of ADA therapy (table 3). Two patients (ADA $\rightarrow$ IFX-1 and -2) achieved remission with subcutaneous ADA therapy for more than 12 months, but the disease then flared up and they were switched from ADA to IFX (table 3). One case (ADA $\rightarrow$ IFX-2) had remission with IFX injection, suggesting that the IFX trough levels were more than $1 \mu \mathrm{g} / \mathrm{ml} 14$ and 54 weeks after the start of IFX therapy ( $5 \mathrm{mg} / \mathrm{kg}$ ). The first case (ADA $\rightarrow$ IFX-1) had a response (reduction in CDAI scores of $\geq 100$ points), but no remission, with IFX injection $(5 \mathrm{mg} / \mathrm{kg}$ ), suggesting that the IFX trough levels were less than $1 \mu \mathrm{g} / \mathrm{ml} 14$ weeks after the start of IFX therapy. Therefore, the IFX dose was escalated to 10 $\mathrm{mg} / \mathrm{kg}$, and the patient achieved remission, suggesting that the IFX trough levels were more than $1 \mu \mathrm{g} / \mathrm{ml}$ at 54 weeks. The remaining patient (ADA $\rightarrow$ IFX-3) had a response (reduction in CDAI scores of $\geq 70$ points), but no remission, with 6-month subcutaneous ADA therapy, showing LOR (table 3). Therefore, this case was switched from ADA to IFX. The IFX dose was escalated to $10 \mathrm{mg} / \mathrm{kg}$, since the patient had a response (reduction in CDAI scores of $\geq 100$ points), but no remission, with IFX injection $(5 \mathrm{mg} / \mathrm{kg})$, suggesting that the CD became worse with a high CRP $(>0.30 \mathrm{mg} / \mathrm{dl})$ at 8 months after the switch from ADA to IFX (table 3; IFX trough levels could not be examined in the ADA $\rightarrow$ IFX-3 case). As a result, this patient achieved remission with a dose escalation of IFX $(10 \mathrm{mg} / \mathrm{kg})$. The 3 patients have maintained remission with IFX treatment after ADA therapy.

\section{Discussion}

The results of the present study show that long-term clinical remission was maintained with ADA as the first TNF- $\alpha$ inhibitor in CD patients for at least 24 months. About $80 \%$ of the CD patients naïve to anti-TNF treatment achieved clinical remission with subcutaneous ADA therapy for at least 24 months (table 2). Two cases retained remission for 5 years (60 months). In the CLASSIC II trial of CD patients naïve to anti-TNF treatment, $79 \%$ who received ADA $40 \mathrm{mg}$ every other week and 83\% who received ADA $40 \mathrm{mg}$ weekly were in remission at week 56 , compared to $44 \%$ with placebo $(p<0.05)$ [4]. In CHARM and its openlabel extension (ADHERE), in which half of the patients were anti-TNF naïve, 37.6, 41.9, and $49.8 \%$ of the patients originally randomized to placebo, ADA every other week, and ADA weekly, respectively, were in clinical remission after up to 2 years of ADA treatment [12]. In addition, at least $30 \%$ of early responders randomized to ADA induction therapy achieved remission at year 4 of ADA treatment in CHARM and ADHERE [5]. In a large populationbased cohort study in North Holland, $83.3 \%$ of CD patients on ADA therapy showed sus- 


\section{Case Reports in Gastroenterology}

Case Rep Gastroenterol 2016;10:283-291

$10.1159 / 000445105$ (c) 2016 The Author(s). Published by S. Karger AG, Basel www.karger.com/crg

Mizoshita et al.: Long-Term Clinical Remission in Biologically Naïve CD Patients with Adalimumab Therapy, Including Analyses of Switch from Adalimumab to Infliximab

tained benefit with maintenance treatment after 1 year, followed by $74.0 \%$ after 2 years [6]. The majority of patients (54\%) with remission at year 1 maintained this endpoint at year 4 [5]. In the present cases, the clinical conditions of 4 CD patients with ADA as the first TNF- $\alpha$ inhibitor were observed for at least 48 months, and all 4 cases maintained remission (table 2 ). Taken together with the previous reports, the present data suggest that long-term clinical remission can be retained in CD patients with ADA as the first TNF- $\alpha$ inhibitor if the remission has continued for at least 24 months.

Complete mucosal healing in early-stage CD patients is associated with significantly higher steroid-free remission rates 4 years after the start of therapy [13]. Clinical remission rates through 3 years of treatment were high in a subgroup with the shortest disease duration ( $<2$ years) among ADA-treated CD patients, with a trend to fewer side effects [14]. CD patients with a disease duration below 2 years maintained higher remission rates than those with a longer disease duration through 3 years of treatment [14]. In the CLASSIC II trial, the average disease duration was 7.73 years among CD patients naïve to anti-TNF treatment who received ADA $40 \mathrm{mg}$ every other week, and $79 \%$ were in remission at 1 year [4]. In the present case series, the average disease duration was 5.6 years among CD patients naïve to anti-TNF treatment who received ADA $40 \mathrm{mg}$ every other week, and $94.1 \%$ were in clinical remission at 1 year (data not shown). Taken together with the previous reports, the present data suggest that ADA therapy is more effective for early-stage CD patients naïve to anti-TNF treatment.

The CD patients who were treated with IFX plus AZA were more likely to have corticosteroid-free clinical remission than those treated with IFX monotherapy in the SONIC study [10]. In the present case series, IFX injection was therefore started after the addition of AZA in 3 CD patients who had LOR despite continuous ADA therapy. Regarding studies of switching TNF- $\alpha$ inhibitors in CD, 32 switched from IFX to ADA, 4 switched from IFX to certolizumab-pegol, and 1 switched from ADA to IFX, suggesting that there is little evidence related to switching from ADA to IFX [7]. Only one report had data on $15 \mathrm{CD}$ patients that switched from ADA to IFX, and that report suggested that switching from ADA to IFX may be useful for CD patients who develop adverse effects or LOR, but a benefit from IFX to primary nonresponders was not established [8]. In the present study of $17 \mathrm{CD}$ patients with ADA as the first TNF- $\alpha$ inhibitor, $3(17.6 \%)$ switched from ADA to IFX, suggesting that all 3 cases achieved remission with IFX therapy. No CD cases developed serious adverse events with ADA therapy. It is well known that the serum trough IFX concentration predicts clinical outcome, and that LOR is related to a decreased serum trough level [9]. It has been shown that dose escalation while maintaining a certain level of IFX is important in achieving remission for CD patients showing LOR to IFX [11]. In 2 of the 3 CD patients switching from ADA to IFX in our study, remission was achieved by dose escalation of IFX (from 5 to $10 \mathrm{mg} / \mathrm{kg}$ ). CD patients treated with IFX and with trough levels higher than $1 \mu \mathrm{g} / \mathrm{ml}$ had a higher chance of achieving steroid-free clinical remission than those with lower IFX trough levels, which is in line with the data for the present CD cases [10] (table 3). As regards LOR to IFX therapy, this phenomenon is considered to be due to a decreased serum trough level $[9,11]$; therefore, a decrease in the dose interval or an increase in the dosage of IFX is recommended for CD patients showing LOR to standard therapy [11]. In Japan, dose escalation of IFX (from 5 to 10 $\mathrm{mg} / \mathrm{kg}$ ) was approved in 2011 for use in CD with LOR to IFX, while a decrease in the dose interval is not approved. Therefore, dose escalation was performed in the $2 \mathrm{CD}$ patients with LOR to IFX (table 3). In addition, none of the patients had serious adverse events requiring termination of ADA and IFX therapies in the present series, suggesting that TNF- $\alpha$ inhibitors are not toxic at a high serum concentration [15]. 
In conclusion, maintenance ADA therapy achieves long-term clinical remission in CD patients naïve to anti-TNF treatment. Switching from ADA to IFX is an important therapeutic option for CD patients having LOR to ADA, and dose escalation is effective for CD patients having LOR to IFX, with analysis of IFX trough levels.

\section{Acknowledgements}

The authors would like to thank Mrs. Yukimi Hashizume for expert technical assistance. This study was supported by a Grant-in-Aid (Kiban C, 26460945) from the Ministry of Education, Culture, Sports, Science and Technology of Japan.

\section{Statement of Ethics}

This study was approved by the Institutional Review Board at Nagoya City University Hospital, and the therapies, including anti-TNF treatment, were performed after informed consent was obtained from the present patients.

\section{Disclosure Statement}

The authors have no conflicts of interest to declare.

\section{References}

1 Mizoshita T, Tanida S, Tsukamoto H, Ozeki K, Katano T, Nishiwaki H, Ebi M, Mori Y, Kubota E, Kataoka H, Kamiya T, Joh T: Adalimumab treatment in biologically naive Crohn's disease: relationship with ectopic MUC5AC expression and endoscopic improvement. Gastroenterol Res Pract 2014;2014:687257.

2 Watanabe M, Hibi T, Lomax KG, Paulson SK, Chao J, Alam MS, Camez A: Adalimumab for the induction and maintenance of clinical remission in Japanese patients with Crohn's disease. J Crohns Colitis 2012;6:160-173.

3 Hanauer SB, Sandborn WJ, Rutgeerts P, Fedorak RN, Lukas M, MacIntosh D, Panaccione R, Wolf D, Pollack P: Human anti-tumor necrosis factor monoclonal antibody (adalimumab) in Crohn's disease: the CLASSIC-I trial. Gastroenterology 2006;130:323-333; quiz 591.

4 Sandborn WJ, Hanauer SB, Rutgeerts P, Fedorak RN, Lukas M, MacIntosh DG, Panaccione R, Wolf D, Kent JD, Bittle B, Li J, Pollack PF: Adalimumab for maintenance treatment of Crohn's disease: results of the CLASSIC II trial. Gut 2007;56:1232-1239.

5 Panaccione R, Colombel JF, Sandborn WJ, D'Haens G, Zhou Q, Pollack PF, Thakkar RB, Robinson AM: Adalimumab maintains remission of Crohn's disease after up to 4 years of treatment: data from CHARM and ADHERE. Aliment Pharmacol Ther 2013;38:1236-1247.

6 Peters CP, Eshuis EJ, Toxopeüs FM, Hellemons ME, Jansen JM, D’Haens GR, Fockens P, Stokkers PC, Tuynman HA, van Bodegraven AA, Ponsioen CY: Adalimumab for Crohn's disease: long-term sustained benefit in a population-based cohort of 438 patients. J Crohns Colitis 2014;8:866-875.

7 Gisbert JP, Marín AC, McNicholl AG, Chaparro M: Systematic review with meta-analysis: the efficacy of a second anti-TNF in patients with inflammatory bowel disease whose previous anti-TNF treatment has failed. Aliment Pharmacol Ther 2015;41:613-623.

8 Chaparro M, Andreu M, Barreiro-de Acosta M, García-Planella E, Ricart E, Domènech E, Esteve M, Meriño O, Nos P, Penalva M, Gisbert JP: Effectiveness of infliximab after adalimumab failure in Crohn's disease. World J Gastroenterol 2012;18:5219-5224.

9 Hibi T, Sakuraba A, Watanabe M, Motoya S, Ito H, Motegi K, Kinouchi Y, Takazoe M, Suzuki Y, Matsumoto T, Kawakami K, Hirata I, Tanaka S, Ashida T, Matsui T: Retrieval of serum infliximab level by shortening the maintenance infusion interval is correlated with clinical efficacy in Crohn's disease. Inflamm Bowel Dis 2012;18:1480-1487. 
Mizoshita et al:: Long-Term Clinical Remission in Biologically Naïve CD Patients with Adalimumab Therapy, Including Analyses of Switch from Adalimumab to Infliximab

10 Colombel JF, Sandborn WJ, Reinisch W, Mantzaris GJ, Kornbluth A, Rachmilewitz D, Lichtiger S, D’Haens G, Diamond RH, Broussard DL, Tang KL, van der Woude CJ, Rutgeerts P: Infliximab, azathioprine, or combination therapy for Crohn's disease. N Engl J Med 2010;362:1383-1395.

11 Suzuki Y, Matsui T, Ito H, Ashida T, Nakamura S, Motoya S, Matsumoto T, Sato N, Ozaki K, Watanabe M, Hibi T: Circulating interleukin 6 and albumin, and infliximab levels are good predictors of recovering efficacy after dose escalation infliximab therapy in patients with loss of response to treatment for Crohn's disease: a prospective clinical trial. Inflamm Bowel Dis 2015;21:2114-2122.

12 Panaccione R, Colombel JF, Sandborn WJ, Rutgeerts P, D’Haens GR, Robinson AM, Chao J, Mulani PM, Pollack PF: Adalimumab sustains clinical remission and overall clinical benefit after 2 years of therapy for Crohn's disease. Aliment Pharmacol Ther 2010;31:1296-1309.

13 Baert F, Moortgat L, Van Assche G, Caenepeel P, Vergauwe P, De Vos M, Stokkers P, Hommes D, Rutgeerts P, Vermeire S, D'Haens G: Mucosal healing predicts sustained clinical remission in patients with early-stage Crohn's disease. Gastroenterology 2010;138:463-468; quiz e10-e11.

14 Schreiber S, Reinisch W, Colombel JF, Sandborn WJ, Hommes DW, Robinson AM, Huang B, Lomax KG, Pollack PF: Subgroup analysis of the placebo-controlled CHARM trial: increased remission rates through 3 years for adalimumab-treated patients with early Crohn's disease. J Crohns Colitis 2013;7:213-221.

15 Brandse JF, Vos LM, Jansen J, Schakel T, Ponsioen CI, van den Brink GR, D’Haens GR, Löwenberg M: Serum concentration of anti-TNF antibodies, adverse effects and quality of life in patients with inflammatory bowel disease in remission on maintenance treatment. J Crohns Colitis 2015;9:973-981.

Table 1. Patients' baseline characteristics $(n=17)$

\begin{tabular}{lc}
\hline Sex (male/female), $\mathrm{n}$ & $11 / 6$ \\
Age at diagnosis, years & $31.9(19-52)$ \\
Age at the start of therapy, years & $36.4(19-64)$ \\
Disease duration, years & $5.6(0.1-21)$ \\
Extent of disease & \\
$\quad$ L1 & $4(23.5)$ \\
L2 & $5(29.4)$ \\
L3 & $8(47.1)$ \\
Perianal disease & $6(35.3)$ \\
Previous surgical resection & $3(17.6)$ \\
Concomitant medication & 5 \\
$\quad$ Prednisolone & 14 \\
$\quad$ 5-Aminosalicylates & 6 \\
$\quad$ Immunosuppressant (AZA) & 5 \\
GMA & 4 \\
$\quad$ Enteral nutrition & 0 \\
$\quad$ Anti-TNF- ${ }^{1}$ & \\
\hline Values are expressed as median (range) or n (\%). GMA = Granulocyte \\
and monocyte adsorptive apheresis; L1 = ileum; L2 = colon; L3 = ileoco- \\
lon. ${ }^{1}$ Previous use of infliximab or a biologic.
\end{tabular}


Table 2. Clinical conditions of the CD patients having continuous treatment with ADA as the first TNF- $\alpha$ inhibitor during 24 months and more $(\mathrm{n}=14)$

\begin{tabular}{lllll}
\hline & CDAI & & & \\
\cline { 2 - 5 } & 0 month & 24 months & 36 months & most recent status (months) \\
\hline ADA-long-1 & moderate & remission & remission & remission (60) \\
ADA-long-2 & moderate & remission & remission & remission (60) \\
ADA-long-3 & mild & remission & remission & remission (54) \\
ADA-long-4 & mild & remission & remission & remission (48) \\
ADA-long-5 & mild & remission & remission & remission (42) \\
ADA-long-6 & moderate & remission & remission & remission (42) \\
ADA-long-7 & moderate & remission & remission & remission (42) \\
ADA-long-8 & mild & remission & remission & remission (36) \\
ADA-long-9 & moderate & remission & remission & remission (36) \\
ADA-long-10 & moderate & remission & remission & remission (36) \\
ADA-long-11 & moderate & remission & - & remission (30) \\
ADA-long-12 & moderate & remission & - & remission (30) \\
ADA-long-13 & moderate & remission & - & remission (24) \\
ADA-long-14 & moderate & remission & - & remission (24) \\
\hline
\end{tabular}

CDAI: remission $=$ score $<150$; mild $=150 \leq$ score $<220$; moderate $=220 \leq$ score $<450$; severe $=$ score $\geq 450$. 1 The patient died from unexpected external injury to the head. 
Mizoshita et al: Long-Term Clinical Remission in Biologically Naïve CD Patients with Adalimumab Therapy, Including Analyses of Switch from Adalimumab to Infliximab

Table 3. Clinical conditions of the CD patients having switched from ADA to IFX after secondary failure of $\operatorname{ADA}(\mathrm{n}=3)$

\begin{tabular}{|c|c|c|c|c|c|c|c|}
\hline & \multirow{2}{*}{$\begin{array}{l}\text { ADA } \\
\text { treatment, } \\
\text { months }\end{array}$} & \multirow{2}{*}{$\begin{array}{l}\text { Reason(s) for } \\
\text { switch from } \\
\text { ADA to IFX }\end{array}$} & \multicolumn{2}{|c|}{$\begin{array}{l}\text { Trough concentra- } \\
\text { tion of IFX, } \mu \mathrm{g} / \mathrm{ml}\end{array}$} & \multirow[t]{2}{*}{$\begin{array}{l}\text { Clinical course after } \\
\text { switch from ADA to IFX }\end{array}$} & \multicolumn{2}{|c|}{ Most recent status } \\
\hline & & & $1 \mathrm{st}^{1}$ & $\begin{aligned} 2 \mathrm{nd}^{2} & \text { dose } \\
& \text { escala- } \\
& \text { tion }\end{aligned}$ & & $\begin{array}{l}\text { IFX treat- } \\
\text { treat- } \\
\text { ment, } \\
\text { months }\end{array}$ & CRP CDAI \\
\hline $\begin{array}{l}\mathrm{ADA} \rightarrow \\
\mathrm{IFX}-1\end{array}$ & 30 & $\begin{array}{l}\text { Flare-up } \\
(\mathrm{CRP}=2.11 \\
\mathrm{mg} / \mathrm{dl} \uparrow) ; \\
\text { the anal fistula } \\
\text { worsened, and } \\
\text { a seton } \\
\text { operation } \\
\text { was performed }\end{array}$ & 0.32 & 1.21 yes & $\begin{array}{l}\text { The patient had } \\
\text { improvement of the } \\
\text { abdominal conditions } \\
\text { but a continuously high } \\
\text { level of CRP ( }>0.30 \mathrm{mg} / \mathrm{dl} \text { ) } \\
\text { after the switch from ADA } \\
\text { to IFX; therefore, a dose } \\
\text { escalation of IFX (from } 5 \text { to } \\
10 \mathrm{mg} / \mathrm{ml} \text { ) was performed, } \\
\text { since the } 1 \text { st trough concen- } \\
\text { tration was }<1 \mathrm{mg} / \mathrm{ml} \text { after } \\
\text { IFX administration }\end{array}$ & 24 & $\begin{array}{ll}- & \text { remis- } \\
& \text { sion }\end{array}$ \\
\hline $\begin{array}{l}\mathrm{ADA} \rightarrow \\
\mathrm{IFX}-2\end{array}$ & 18 & $\begin{array}{l}\text { The anal } \\
\text { fistula } \\
\text { worsened, and } \\
\text { a seton opera- } \\
\text { tion was per- } \\
\text { formed }\end{array}$ & 6.25 & 2.85 no & $\begin{array}{l}\text { The patient had remission } \\
\text { after the switch from ADA } \\
\text { to IFX, and the trough con- } \\
\text { centration was }>1 \mathrm{mg} / \mathrm{ml} \text { at } \\
\text { both the } 1 \text { st and the } 2 \mathrm{nd} \\
\text { analysis after IFX admin- } \\
\text { istration }(5 \mathrm{mg} / \mathrm{ml})\end{array}$ & 30 & $\begin{array}{ll}- & \text { remis- } \\
& \text { sion }\end{array}$ \\
\hline $\begin{array}{l}\text { ADA } \rightarrow \\
\text { IFX-3 }\end{array}$ & 6 & $\begin{array}{l}\text { Flare-up } \\
(\mathrm{CRP}=2.60 \\
\mathrm{mg} / \mathrm{dl} \uparrow)\end{array}$ & $\begin{array}{l}\text { not } \\
\text { exam- } \\
\text { ined }\end{array}$ & $\begin{array}{l}\text { not yes } \\
\text { exam- } \\
\text { ined }\end{array}$ & $\begin{array}{l}\text { The patient had temporary } \\
\text { improvement of the ab- } \\
\text { dominal conditions, but they } \\
\text { became worse, with a high } \\
\text { level of CRP (>0.30 mg/dl) } 8 \\
\text { months after the switch } \\
\text { from ADA to IFX; therefore, } \\
\text { a dose escalation of IFX } \\
\text { (from } 5 \text { to } 10 \mathrm{mg} / \mathrm{ml} \text { ) was } \\
\text { performed }\end{array}$ & 18 & $\begin{array}{ll}- & \text { remis- } \\
& \text { sion }\end{array}$ \\
\hline
\end{tabular}

CDAI: remission $=$ score $<150$; mild $=150 \leq$ score $<220$; moderate $=220 \leq$ score $<450$; severe $=$ score $\geq 450$. CRP: - is $\leq 0.30 \mathrm{mg} / \mathrm{dl} ;+$ is $>0.30 \mathrm{mg} / \mathrm{dl}$. ${ }^{1} \mathrm{An}$ IFX injection was performed at 0,2 , and 6 weeks, and the $1 \mathrm{st}$ analysis of the trough concentration was examined at 14 weeks just before the 4 th IFX injection. ${ }^{2}$ An IFX injection was performed every 8 weeks after the 4 th administration, and the 2 nd analysis of the trough concentration was examined at 54 weeks, just before the 9 th IFX injection. 